\title{
Yoga: A Pathway to Tap Into the Cosmic Consciousness
}

\author{
Deepak Shimkhada* \\ Claremont School of Theology, USA
}

Submission: June 29, 2017; Published: July 05, 2017

*Corresponding author: Deepak Shimkhada, Adjunct Professor, Claremont School of Theology, USA, Tel: 909-237-2667

Email: dshimkhada@gmail.com

\section{Opinion}

One night I found myself seated at a table with a group of eminent people, enjoying dinner after attending an invitational lecture at the college where I taught. There was a biologist and a physicist in our midst; I was the only person qualified to be called a humanist. That particular semester I was teaching a course called "Theory and Practice of Yoga." In one conversation during the evening, the lady sitting next to me, the wife of another guest, a successful entrepreneur, asked about my background. When I explained that I was a professor of religious studies, she was fascinated and we became engaged in serious conversation about theology and yoga, not necessarily in that order.

This guest told me that she joined a yoga class against her husband's wishes. She was glad she did it; it helped her both mentally and physically. Needless to say, I was pleased with this volunteered affirmation that clearly showed she was in my camp. I had a visceral feeling, however, that her husband and my biologist neighbour were not comfortable with the direction the conversation was heading. Finding an ally in her, I showed enthusiasm in our philosophical discourse by delving deeper into the subject of being and non-being. Perhaps experiencing a little jealousy about my coziness with the woman, the biologist blurted out, "What exactly does your course consist of? "This is a course syllabus question that students usually ask before signing up for the class, so I was well prepared to respond.The manner in which he framed the question, with a grain of disdain, made me suddenly aware that he was questioning the validity of science over Eastern philosophy, with the implication that it is suspect.

I gave him a straight answer: "The course consists of two major parts: theory and practice. First, I teach the philosophical foundations of yoga, on which the whole system is based. I use Yoga Sutra by Patanjali, the great yoga exponent who compiled the text. The second part consists of practice, or the physical aspect of it,which includes breathing and physical exercises."
This was followed by another question from our biologist: "What qualifies you to teach the course? Do you practice it yourself at home?" I explained that I practice yoga, but not Hatha yoga. "I mostly do pranayama and meditation. I don't contort my body, not because I don't like it, but because my body simply doesn't cooperate at my age." His line of questioning continued. "When you say pranayama, what does that mean? Frankly, I am not a fan of yoga, even though there is a yoga studio down the road where I live."

I wasn't thrown by his questions and was happy to indulge him. "I am glad that you asked.The word pranayama is derived from the Sanskrit word prana, meaning life force (that is, breath). So in a simple sense, pranayama is the regulation of breath or breathing exercise." I continued as if I were lecturing in the classroom. "In yoga tradition, the body is like the vehicle and the mind is the driver. If the driver isn't trained to remain in control of his vehicle, the body, he is bound to cause an accident. Pranayama (breathing techniques) and meditation (dhyana) are two key elements that the practitioner must be in control of. Each morning I sit down to practice pranayama. Through deep breathing I try to restrain my mind, as recommended by Patanjali some eighteen hundred years ago, if you believe in the chronology proposed by some. Patanjali explains that yoga as a discipline is designed to restrain one's mind from taking various forms. For example, the second aphorism in the text opens with the line yogashchittavrittinirodhah, which means "yoga is the control of mind". Although it's a simple one liner, it's steeped in deep philosophical discourse." The biologist struck back with his own explanation that one doesn't have to go through all this "mumbo jumbo" (his exact words) to breathe. "Breathing is a biological function that all living beings do in order to survive. Why would you spend your precious time to practice breathing?".

"To calm the monkey mind. Conscious deep breathing does simply that," I replied. "That is ridiculous to be conscious of your own breath," he shot back. "I don't need to be conscious of my 
nature's given biological function. Conscious or unconscious, I breathe, and all living beings breathe. The day we stop breathing we die. I don't have time to sit down to count my breathing. I do it naturally. That's just ridiculous!" I calmly responded, "That is true. However, Patanjali understood the human body and developed a system by which one can be at peace with his own self through quieting the mind.The human mind, by nature, is not stable; it wanders everywhere faster than the speed of light. A mind that is controlled can achieve many extraordinary things". To make a long story short, the biologist wasn't willing to accept my Eastern view on life. No matter how hard I tried to convince him, he remained true to his Darwinian views.

The human body is a microcosm of macrocosm.We are comprised of five great elements, which are called panchamahabhuta in Hinduism. Similarly, the blue planet, which we call our home, is made up of $70 \%$ water while the rest is land mass. Our body reflects approximately this same ratio. Since a large part of the human body is oxygen, breathing is necessary to regulate its functions. Breathing involves two actions: inhaling and exhaling. We inhale oxygen and exhale carbon dioxide. The functions of inhaling and exhaling, in biological terms, have been explained by Seethalakshmy Nagarajan: "A depletion of carbon dioxide can result in chest tendering and throbbing pain, high or low blood pressure, angina, hypertension, and tachycardia. Asthmatics quickly can overcome asthma assaults by reinstating carbon dioxide levels, which expands bronchial pathways. If the inter-exchange of oxygen and carbon dioxide is done correctly while practicing the correct breathing technique, then it will balance the $\mathrm{pH}$ level of the body. The equilibrium gained by this practice will affect the nervous system directly awakening in this way the parasympathetic branch. This will, in turn, make the mind calm and open, and a sense of well-being will ensue, and a trance like state in which the person sporadically has numinous understanding will take over him."

If we compare the process of inhaling and exhaling in biological and yogic terms, we will find a correlation between the two. In yogic practice, inhaling is considered birth and exhaling death. According to this belief, we live and die every moment through the simple biological process of inhaling and exhaling.Taking more oxygen through deep breathing is more beneficial to our health and, in theory, promotes long life. Apart from the obvious, breathing has many benefits, particularly deep, conscious breathing where the monkey mind is restrained from wandering. Once the mind is restrained, it can be put to focus on a bindu (a point). What's that point? It's entirely up to the practitioner. The calmer mind can then connect to the cosmic consciousness and be one with it.

We all are a part of the cosmic web of consciousness. To prove my point at the dinner party I cited the book The SelfAware Universe: How Consciousness Creates the Material World by physicist Amit Goswami et al. who claims that consciousness affects the quantum wave. The physicist, who sat three seats away from me, finally joined in the conversation. He added, "I see your point. There is a connection between human consciousness and cosmic consciousness. Everything is part of the grand design; nothing is unconnected, even at the quantum level." With the physicist's affirmation, I felt vindicated; it was smooth sailing from thereon out. Today, especially in the West, there is resistance to accepting yoga as a spiritual system. It's packaged as a fitness program in many studios, with lauded benefits ranging from having a better butt to better sex. The spiritual aspect has been neglected, being one with God, the Cosmic Consciousness. This is the ultimate goal of yoga.

\section{Your next submission with Juniper Publishers} will reach you the below assets

- Quality Editorial service

- Swift Peer Review

- Reprints availability

- E-prints Service

- Manuscript Podcast for convenient understanding

- Global attainment for your research

- Manuscript accessibility in different formats ( Pdf, E-pub, Full Text, Audio)

- Unceasing customer service

Track the below URL for one-step submission https://juniperpublishers.com/online-submission.php 